THE COMPLEMENTARITY OF REGULATORY AND INTERNAL GOVERNANCE MECHANISMS IN BANKS

WORKING PAPER DRM FINANCE 2008-1

\section{HERVÉ ALEXANDRE}

UNIVERSITÉ PARIS DAUPHINE, DRM

Place du Maréchal de LatTRe DE

TASSIGNY

75775 PARIS CEDEX 16

herve.alexandre@,dauphine.fr

\section{KARIMA BOUAISS}

\section{CERMAT}

QUARTIER DES DEUX LIONS

50 Avenue JeAn Portalis

BP 0607 - 37206 TOURS CEDEX 03

karima.bouaiss@univ-tours.fr

JEL Classification: G21 - G32 - G38 
Abstract:

Decisions taken by the manager of a bank are subject to the regulatory discipline of the Basel Committee in conjunction with the supervisory discipline of the Board of Directors, a body that represents shareholders. This research demonstrates that the two types of discipline act in complement to each other, whereas the extant literature shows that regulatory discipline is replacing the internal discipline exercised by the Board of Directors. We also show that these internal and external governance mechanisms are relevant to explain the simultaneous influences between financial performance, risk-taking and the capitalization of French banks from 1998 to 2004.

Keywords:

Bank governance, banking regulation, risk-taking, capital adequacy, financial performance 


\section{1 - INTRODUCTION}

In February 2006, the Basel Committee stressed the need to strengthen good governance practices in banks. The Committee recommended that managerial discipline roles should be shared between the board of directors and the controlling authorities. The board of directors, to consist of a larger number of independent directors, should be responsible for approving the bank's strategies and values, ensuring respect of the hierarchy and transparency of management, and motivating and supervising management, with particular focus on its audit role as part of a coherent overall approach. In complement, the controlling authorities should be responsible for issuing the guidelines needed to ensure banks meet one of the Committee's major objectives: depositor protection. The primary role of the authorities was to be the "supervisor of supervision". They were mainly in charge of developing board and management empowerment, together with verification of good governance practices and control of audit. It is clear from the "Core Principles for Effective Banking Supervision" report published by the Basel Committee in 2006 that the internal control exercised by the board of directors and the external control exercised by the controlling authorities complement each other.

This article belongs to the literature on corporate governance, in the more specific framework of governance of banks. The Basel Committee's report stresses the relevance and importance of using a combination of internal and external discipline over decisions made by the bank's manager, in order to maximize value creation. The objective is to compare this theoretical and now regulatory framework of governance with the reality of French banking practices. To do so, we shall compare the discipline exercised by Basel Committee regulations under the 1988 Accord (since amended) with the internal discipline exercised by the board of directors.

The major contribution of this research lies in its focus on the two apparently contradictory pressures faced by the manager:

- $\quad$ Regulations, designed to protect depositors and avoid systemic risk, force the bank to limit risk-taking by imposing a minimum capitalization requirement,

- The board of directors, as a shareholder representative body, seeks to maximize shareholder value even when greater risk-taking will be involved.

What are the relative influences of board discipline and regulatory demands in respect of the manager's triple objective of maintaining a required capitalization level, taking risks and achieving good performances? 
To answer this question, we examine the French banking sector from 1998 to 2004. We seek to understand the concurring trends in French banks' capitalization, risk level and performance, based on internal governance and regulatory variables. We show that the two governance mechanisms complement each other, although the literature examining the question in the banking sector finds that regulatory discipline is replacing internal board discipline.

This article is structured as follows. First, we propose a review of the extant literature on governance of banks (section 2), which forms a basis for our proposed model of the issues (section 3), before reporting the results of our study on a French sample (section 4).

\section{2 - CORPORATE GOVERNANCE OF BANKS: A REVIEW OF THE LITERATURE}

Examination of past research on the corporate governance of banks reveals its specificities compared to corporate governance of business organizations in general. The importance of regulation ${ }^{1}$, the complexity of agency problems ${ }^{2}$ and the low capitalization rate in the banking sector are the key factors that make governance of banks substantially different from governance of industrial firms (Ciancanelli and Gonzalez, 2000). For better understanding of this specificity, we present the role of banks' boards of directors before comparing them with the external mechanism of regulations. Finally, we focus on the special link between governance and risk-taking for banks.

\subsection{The board of directors, an internal managerial discipline mechanism}

The Board of Directors is the primary mechanism of the internal control system, serving to discipline and set game rules with the manager. Jensen (1993) presents the factors required to enable the board of directors to act as an effective control mechanism, including:

- Free access to relevant information for board members.

- Ownership by the manager and board members of a significant number of shares in the firm, in order to ensure a certain alignment of interests with shareholders.

- A limited number of directors (seven or eight) to foster efficiency, but enough to

1 Bank governance is unusual due to the sector's high degree of regulation (Ciancanelli and Gonzalez, 2000; Llewellyn, 2001; Booth et al., 2002; Macey and O'Hara, 2003 and Berger and Bonaccorsi di Patti, 2003), intended to limit bank bankruptcies by curbing systemic risk (Llewellyn 2001, Basel Committee 1988 and 2004). 2

Agency problems are more complex, particularly with regard to information asymmetry that affects not only the shareholder-manager relationship, but also:

- The relationship between depositors, the bank and the regulating authorities

- The relationship between shareholders, the manager and the regulating authorities

- The relationship between borrowers, the manager and the regulating authorities. 
prevent the board being controlled by the manager. In respect of banks, Booth et al. (2002) and Adams and Mehran (2003 and 2005) find that banks' boards of directors are larger in size (with 16 members on average). Contrary to Jensen's explanations, Adams and Mehran (2005) find no negative association between board size and performance, suggesting that restrictions on board size in the banking sector may be counterproductive.

- Similarly, the manager should be the only internal member of the board, because the presence of any other internal members could help the manager to influence the board.

- The functions of manager and the chairman of the board of directors should not be held by the same person.

\subsection{Combination of internal and regulatory mechanisms}

Corporate governance of banks is characterized by internal mechanisms designed to influence and monitor the manager's behaviour, but also by external mechanisms such as regulation, which are extremely important in this sector.

In his work on takeovers in the banking sector, Prowse (1995) looks at the disciplinary mechanisms applicable to managers of banks. He compares the banking sector with other sectors of industry, and highlights that banks' boards of directors are weak effective managerial discipline mechanisms compared with the threat of a hostile takeover as an external mechanism. Observing that manager turnover in banks is twice as low as in other firms, he explains this by reference to the structure of the board. Banks' boards of directors are mostly made up of internal directors who reinforce the manager's observed entrenchment. The low rate of external directors is explained by low ownership of shares in the bank, providing little incentive to discipline the manager effectively. Prowse also shows that intervention by the regulatory authorities increases with the bank's size and the degree of performance deterioration.

These results were confirmed by Booth et al. (2002), who study the possibility of limiting conflicts of interest between the manager and the shareholders. They look at four mechanisms for managerial discipline: one external mechanism, regulation, and three internal mechanisms: board member independence, share ownership by the manager and separation of the functions of manager and chairman of the board. Booth et al. explain that one of these four mechanisms may be more important in managing divergent interests in a shareholder approach. In highly regulated sectors like the banking sector, the discipline exercised by regulation is replacing banks' internal governance mechanisms and therefore limiting his 
latitude for action. The importance of regulatory discipline is explained by its major role in developing a durably sound, stable banking sector, particularly through Basel Committee capital adequacy regulations, and the regulation of deposit insurance. This major role interferes directly with the shareholder-management relationship.

In a similar vein, Bouwman (2004) examines the interaction between three bank governance mechanisms: capital requirements, regulatory supervision and supervision by the dominant shareholders, and the impact of these three mechanisms on risk-taking and performance after an acquisition. Capitalization requirements and regulatory supervision are substitutable mechanisms in monitoring banks' acquisition behaviour, which is shown to subsequently affect risk-taking and the performance of the acquisition. Shareholder supervision then replaces supervision by the regulatory authorities when it is ineffective, and vice versa.

\subsection{Bank governance and risk-taking}

The study of corporate governance throws special light on the performance of banks. Saunders et al. (1990) propose an explanation of the effects of capital regulation on risktaking by banks. They hypothesize that shareholder-controlled banks ${ }^{3}$ have a greater incentive to take risks than manager-controlled banks ${ }^{4}$. They validate the hypotheses that banks controlled by shareholders are riskier than banks controlled by the manager, and add that this difference in risk-taking is more significant in periods of deregulation (particularly between 1979 and 1982). This shows that the existence of regulations can limit and reduce incentives to take greater risks. Saunders et al. recommend stricter monitoring by the authorities for shareholder-controlled banks, in order to contain their risk-taking.

Demsetz et al. (1997) analyse the links between agency costs specific to the banking sector and risk-taking by banks. They argue that when there are conflicts of interest between shareholders and the manager, the latter's risk aversion offsets the excessive risk-taking associated with using loopholes in the deposit insurance system, leading to the emergence of a moral hazard. They observe a strong association between ownership structure and risk-taking when the bank's franchise ${ }^{5}$ value is low. A low franchise value is associated with excessive

\footnotetext{
3 Situation in which the manager is also a significant shareholder and seeks to maximise shareholder returns.

$4 \quad$ Situation in which ownership is diffuse and the portion of shares held by the manager is not significant, potentially giving him latitude to act in his own interests, to the detriment of shareholders.

The franchise value is defined as the potential profit generated by the firm, and can reduce risk-taking. Keeley (1990) explains the decline since the 1970s in US bank franchise values by the rise in the probability of default caused by use of risky assets and reduction of capitalization. This excessive risk in banks' risk-taking is
} 
risk-taking due to the moral hazard problem and exacerbated conflicts of interest between shareholders and manager. Demsetz et al. show that managerial share ownership (implying that the manager's interests will be aligned with those of shareholders) influences risk-taking via significant use of risky assets, whereas concentrated ownership, particularly in the hands of external shareholders, influences risk-taking more through financial levers. This confirms the findings of Keeley (1990) and shows that external shareholders exercise more pronounced control over the manager's risk-taking decisions, more through influencing financial structure than by active management of risky assets.

The work of Demsetz et al. supports the results reported by Gorton and Rosen (1995), who propose an explanation for the rise in risks in the 1980s that led several banks to collapse. They show that agency problems related to the limited control exercised by shareholders offer a more relevant explanation for the rise in risks than the moral hazard generated by the deposit insurance system. Shareholders do not directly participate in development of the bank's asset portfolio, which is the manager's job, and only have imperfect control over the decisions of the manager, who will be inclined to greater risktaking when the banking sector is in difficulty. This behaviour is explained by the entrenchment of the manager who holds a share in the bank large enough to circumvent the discipline exercised by shareholders, but not large enough to align his interests with shareholders' interests.

Jeitchko and Jeung (2005) show that the importance of the risk preferences of the bank's key actors determines the bank's level of risk. They show that shareholders have more incentive to be less risk-averse in the banking sector, due to the benefits that can be drawn from the deposit insurance system (Merton, 1977). However, the authorities which guarantee the deposits seek to limit the funds allocated to insurance of deposits representing a major illiquidity risk for the bank being assisted, and are in favour of a "conservative policy" for risk-taking, i.e. are more risk-averse than the shareholders. The same is true of the bank's manager, who is considered more risk-averse than shareholders because he has a personal interest in ensuring durability of business for his organization (thus confirming Saunders et al., 1990).

explained by exploitation of the deposit insurance system, which accentuates the moral hazard engendered by the depositor protection programme. However, this excessive risk-taking is mitigated by the regulatory costs of bankruptcy, which can be predicted based on potential losses in terms of franchise value in the event of bankruptcy. A similar result is observed by Gonzales (2005), who shows that regulatory restrictions, particularly for deposit insurance, lead banks to take more risks and therefore to weaken their franchise value. 


\section{3 - MODELling OF THE CAPITAL ADEQUACY RATIO AND CORPORATE GOVERNANCE OF} BANKS

Research into corporate governance shows that shareholders are less markedly riskaverse than the manager, because they are able to diversify their share portfolio while the manager is more personally implicated. If higher returns are expected, shareholders may accept risk-taking above the level "tolerated" by the regulations for a given capitalization level. This relationship is reminiscent of the work of Kahane (1977), Koehn and Santomero (1980) and Rochet (1992) who demonstrate the ineffectiveness of regulations to force banks not to invest in the riskiest assets. This positive relationship between risk level and capitalization is analysed differently from the agency theory angle by Saunders et al. (1990), who show that the manager of a bank with a highly risky asset portfolio offsets those risks by lower financial leverage, i.e. raising the level of equity, and vice versa.

This positive relationship has also been highlighted in the empirical literature analysing the impact of capital regulation on risk-taking by banks. A study by Shrieves and Dahl (1992) laid the foundations for most subsequent empirical research. It proposes a model of the relationship between the level of equity and the level of risk that advances understanding of this relationship's simultaneous nature. A positive, simultaneous relationship is found between changes in the level of risk and changes in the bank's capitalization. This result shows that regulation is effective in influencing decisions concerning the bank's capitalization and risk-taking. Regulatory constraints can limit risktaking by banks, as proved by Ediz et al. (1998) for British banks, Aggarwal and Jacques (2001) for US banks, Rime (2001) for Swiss banks, Murinde and Yaseen (2004) for African and Middle Eastern banks, and Godlewski (2005) for banks in emerging countries. These papers show that the regulating authorities exercise significant discipline over bank capitalization.

A large number of other studies, also heirs of the model proposed by Shrieves and Dahl (1992), come to a slightly different conclusion, supporting a negative relationship between the capitalization and risk levels in banks. Jacques and Nigro (1997) for US banks, Van Roy (2003) for banks in G10 countries and Heid et al. (2004) for German banks arrive at this conclusion, explaining that capital regulation increases the Cooke ratio and reduces the portfolio risk for the banks studied ${ }^{6}$.

\footnotetext{
6 All these authors conclude that capital regulation is effective, particularly the 1988 Basel Committee regulations. However, the difference between the sign of the relationship depends on the indicator used to capture capital levels. Research finding a positive relationship, such as Shrieves and Dahl, uses equity over total
} 
Drawing on this research, we can postulate that the pressure exercised by regulations intended to limit risk-taking is inversely proportional to the pressure from shareholders whose objective is to maximise their returns. Starting from these two contradictory pressures on the manager's decisions regarding the content of the bank's asset portfolio, our model seeks to capture the effects of these pressures on the bank's performance.

As performance is assessed through the risk-return tradeoff, we consider it relevant to select three endogenous variables for our model:

- Performance, measured by the change in return on equity.

- Capitalization, measured by the capital adequacy ratio: equity over total assets.

- The bank's risk-taking, measured by the following ratio: risk-weighted assets (the denominator of the Cooke ratio) over total assets.

These two measures of capitalization and risk-taking were applied in the work by Shrieves and Dahl (1992), Rime (2001), Heid et al. (2004) and Murinde and Yaseen (2004).

Table 1: Summary of simultaneous influences identified by the literature

\begin{tabular}{|l|c|c|c|}
\hline Sign of the relationship & $\begin{array}{l}\text { Change in risk level } \\
\text { and capitalization }\end{array}$ & $\begin{array}{l}\text { Change in } \\
\text { performance and } \\
\text { capitalization }\end{array}$ & $\begin{array}{l}\text { Change in risk level } \\
\text { and performance }\end{array}$ \\
\hline Shrieves and Dahl (1992) & + & Not tested & Not tested \\
\hline Jacques and Nigro (1997) & - & Not tested & Not tested \\
\hline Rime (2001) & + but non-significant & + (ROA) & Not tested \\
\hline $\begin{array}{l}\text { Aggarwal and Jacques } \\
(2001)\end{array}$ & + & Not tested & Not tested \\
\hline Van Roy (2003) & - & + (ROA) & Not tested \\
\hline $\begin{array}{l}\text { Heid, Porath and Stolz } \\
(2004)\end{array}$ & + but non-significant & + (ROA) & - \\
\hline Murinde and Yaseen (2004) & - & + (ROA) & \\
\hline Godlewski (2004) & + & + ROA) & \\
\hline
\end{tabular}

The explanatory variables for our model are external discipline and internal discipline variables, and variables assessing the degree of managerial latitude.

The first variables are those that capture regulatory discipline:

- REG1 is an explanatory variable reflecting the difference between the bank's 
capital adequacy ratio and the minimum level required by regulations, i.e. $8 \%$. This variable measures the scale of the bank's "safety cushion".

- REG2 is a variable measuring the speed at which the bank adjusts its capital adequacy ratio to regulatory standards. It is the product of the distance from the $8 \%$ minimum requirement (REG1) and the bank's capital adequacy ratio at the start of the period $\left(\mathrm{CAP}_{\mathrm{t}-1}\right)$.

The variables capturing the control mechanisms implemented by the board of directors to discipline managerial decisions are derived from the work of Jensen (1993) under the agency theory, and most research on corporate governance of banks:

- TAILLE (size) is the number of directors on the board of directors (BD).

- INDEP is the proportion of independent directors on the $\mathrm{BD}^{7}$.

- $\mathrm{PDG}^{8}$ is the proportion of managers from other firms who are members of the bank's BD. This variable measures the effectiveness of board supervision, as a certain number of directors have the same decision-making functions in other firms, which means peer discipline is possible as explained by Jensen and Fama (1983).

The last variables concern manager characteristics which indicate a certain managerial latitude:

- AGE refers to the manager's age. This variable draws on the managerial entrenchment theory, as studied by Shleifer and Vishny (1989), suggesting that a manager close to retirement can deliberately make his services essential to his firm, such that replacing him can be extremely costly for shareholders.

- MANPDG indicates the number of CEO positions held by the manager, which reflects his managerial latitude in decision-making functions. Holding many CEO positions may indicate that a manager has a certain latitude to act in his own interests rather than the interests of shareholders.

\footnotetext{
$7 \quad$ According to the definition given in the Medef-Afep report of July 1999: "A director is independent of the corporation's management when he or she has no relationship of any kind whatsoever with the corporation or its group that is such as to jeopardize exercise of his or her free judgement." Angbazo and Narayanan (1997) consider directors who are not, and have never been, employed by the bank as independent directors.

8 In French, PDG stands for "Président-Directeur Général", equivalent to (Chairman and) Chief Executive Officer.
} 
Using these variables, the model's three equations are developed:

- The performance change equation

$\Delta \mathrm{ROE}_{\mathrm{j}, \mathrm{t}}=\mathrm{a}_{0}+\mathrm{a}_{1} \Delta \mathrm{CAP}_{\mathrm{j}, \mathrm{t}}+\mathrm{a}_{2} \Delta \mathrm{RISK}_{\mathrm{j}, \mathrm{t}}+\mathrm{a}_{3} \operatorname{INDEP}_{\mathrm{j}, \mathrm{t}}+\mathrm{a}_{4} \operatorname{TAILLE}_{\mathrm{j}, \mathrm{t}}+\mathrm{a}_{5} \operatorname{PDG}_{\mathrm{j}, \mathrm{t}}+\mathrm{a}_{6} \mathrm{AGE}_{\mathrm{j}, \mathrm{t}}+$ $\mathrm{a}_{7} \mathrm{MANPDG}_{\mathrm{j}, \mathrm{t}}+\mathrm{a}_{8} \mathrm{REG} 2-\alpha_{1} \mathrm{ROE}_{\mathrm{j}, \mathrm{t}-1}+\omega_{\mathrm{j}, \mathrm{t}}$

- The capitalization change equation

$\Delta \mathrm{CAP}_{\mathrm{j}, \mathrm{t}}=\mathrm{b}_{0}+\mathrm{b}_{1} \Delta \mathrm{ROE}_{\mathrm{j}, \mathrm{t}}+\mathrm{b}_{2} \Delta \mathrm{RISK}_{\mathrm{j}, \mathrm{t}}+\mathrm{b}_{3} \operatorname{INDEP}_{\mathrm{j}, \mathrm{t}}+\mathrm{b}_{4} \mathrm{TAILLE}_{\mathrm{j}, \mathrm{t}}+\mathrm{b}_{5}$ PDG $_{\mathrm{j}, \mathrm{t}}+\mathrm{b}_{6} \mathrm{AGE}_{\mathrm{j}, \mathrm{t}}$ $+\mathrm{b}_{7} \mathrm{REG} 2_{\mathrm{j}, \mathrm{t}}-\beta_{1} \mathrm{CAP}_{\mathrm{j}, \mathrm{t}-1}+\varepsilon_{\mathrm{j}, \mathrm{t}}$

- The risk level change equation

$\Delta \mathrm{RISK}_{\mathrm{j}, \mathrm{t}}=\mathrm{c}_{0}+\mathrm{c}_{1} \Delta \mathrm{ROE}_{\mathrm{j}, \mathrm{t}}+\mathrm{c}_{2} \Delta \mathrm{CAP}_{\mathrm{j}, \mathrm{t}}+\mathrm{c}_{3} \operatorname{INDEP}_{\mathrm{j}, \mathrm{t}}+\mathrm{c}_{4} \mathrm{TAILLE}_{\mathrm{j}, \mathrm{t}}+\mathrm{c}_{5} \mathrm{PDG}_{\mathrm{j}, \mathrm{t}}+\mathrm{c}_{6} \mathrm{AGE}_{\mathrm{j}, \mathrm{t}}+$ $\mathrm{c}_{7} \mathrm{MANPDG}_{\mathrm{j}, \mathrm{t}}+\mathrm{c}_{8}$ REG1 $_{\mathrm{j}, \mathrm{t}}-\varphi_{1}$ RISK $_{\mathrm{j}, \mathrm{t}-1}+\mathrm{v}_{\mathrm{j}, \mathrm{t}}$

\section{4- ANALYSES OF THE FRENCH BANKING SECTOR}

After presenting our model, we proceed to empirical validation using data from the French banking sector. After a presentation of the validation protocol, a brief descriptive study of our sample is proposed, followed by the simultaneous estimation of our model.

\subsection{Description of the data and methodology}

This study covers the eighteen major French banks from 1998 up to 2004, the year the Basel Committee adopted the McDonough reform.

The data comes from a database constructed from the banks' annual reports, complemented by the Dafsa database of directors and the "Guide des états-majors" (a French directory of the management of the country's top firms) for the years covered by our study. The simultaneous estimation was carried out based on the three-stage least squares method $(3 \mathrm{SLS})^{9}$.

\subsection{Descriptive study of French banks from 1998 to 2004}

It is visible from the factual data for both European banks (Bouaiss, 2008) and French banks that the Cooke ratio for these banks is higher than the minimum $8 \%$ required by the

\footnotetext{
9 The three stage least squares (3SLS) method appears the most appropriate to estimate the system of simultaneous equations, as shown by the specification test applied through a Hausman test in the version developed by Spencer and Berk (1981). This method has also been used in the work of Jacques and Nigro (1997), Rime (2001), Aggarwal and Jacques (2001), Van Roy (2003), Murinde and Yassen (2004) and Godlewski (2004).
} 


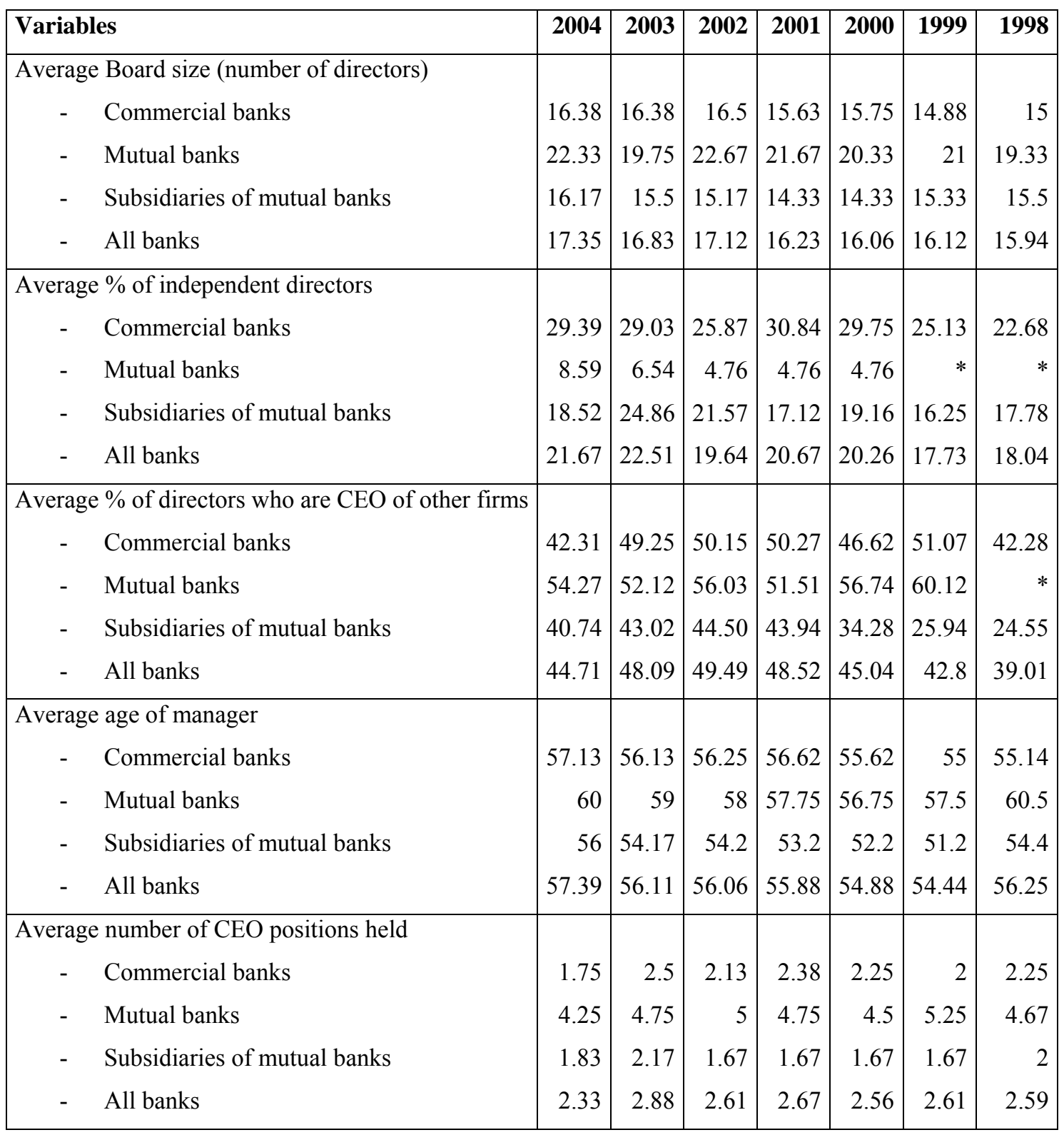

*: information not available

Adams and Mehran also note that the BD has more independent (external) directors, indicating a greater degree of independence than in other types of firm $(68.7 \%$ compared to the average $60.6 \%$ ) and more pronounced control by these independent directors. For our French sample, we observe that the average number of independent directors over the period is approximately $20 \%$, indicating that France is a case apart. We also note a clear difference between the average number of independent directors in mutual banks' BDs compared to other banks' BDs. This relatively small number ( 6 members on average) is explained by the very nature of mutual banks (the parent companies), whose purpose is to "coordinate" the activities of each of the regional banks in the group. The parent company BDs are often made up of the General Managers of the regional banks, and therefore have fewer directors from outside the group. 
The final variable capturing the control exercised by the BD is the average percentage of directors who are managers of other firms. This variable is a proxy for the control exercised by peers, i.e. individuals exercising similar management functions in other organizations. Across the whole sample, approximately $45 \%$ of board members are also managers, underlining the large potential for control by this type of director. There are more manager-directors in mutual banks, consistent with the arguments on the importance of independent directors, who compensate for the "deficit" of control by independent directors by providing a higher level of peer control.

On the variables capturing managerial latitude, we see that the average age of managers in the large French banks is approximately 56, noting that managers of mutual banks are older (average age 58). There are very sharp differences in the number of CEO positions held by managers of banks. On average, for the whole sample, we note that managers of French banks hold some 2.6 CEO positions, with a considerable difference for managers of mutual banks, who hold an average of more than 4, while managers of their subsidiaries hold slightly under 2 .

\subsection{Econometric analysis}

In continuation of the descriptive study, we propose an analysis of two systems of equations (tables 2 and 3): we decided first to focus solely on external governance variables, then to include internal variables related to the discipline exercised by the board. The results of the two estimations are analysed in two stages: first, we examine the influences between the model's three endogenous variables: performance, capitalization and risk level; we then put forward some explanations for these three endogenous variables, drawing on internal and external governance variables.

\subsubsection{Simultaneity of influences between the model's endogenous variables}

Simultaneous effects between the model's three endogenous variables are visible in tables 2 and 3. These results are present in both regressions, highlighting the interaction between banks' financial performance, their capitalization and their risk-taking behaviour.

\section{Table 3: Results of the simultaneous estimation using regulatory variables}

ROE: change in performance (net income/book equity), $\triangle \mathrm{CAP}$ : change in capitalization (equity/total assets), $\triangle$ RISK: change in risk level (risk: risk-weighted assets/total assets), $\operatorname{ROE}\{1\}$ : previous year's $\operatorname{ROE}, \operatorname{CAP}\{1\}$ : previous year's equity, RISK $\{1\}$ : previous year's risk level, REG1: bank's capital adequacy ratio - 8\%, REG2: speed at which the bank adjusts its capital adequacy ratio to regulatory requirements $\left(\mathrm{REG} 1 * \mathrm{CAP}_{\mathrm{t}-1}\right)$. 


\begin{tabular}{|c|c|c|c|c|c|c|c|c|}
\hline \multicolumn{3}{|c|}{$\begin{array}{l}\text { Performance equation } \\
\text { Variable explained }=\Delta \mathrm{ROE}\end{array}$} & \multicolumn{3}{|c|}{$\begin{array}{l}\text { Capitalization equation } \\
\text { Variable explained }=\Delta \mathrm{CAP}\end{array}$} & \multicolumn{3}{|c|}{$\begin{array}{l}\text { Risk equation } \\
\text { Variable explained }=\Delta \text { RISK }\end{array}$} \\
\hline \multicolumn{9}{|c|}{ Usable observations: 81} \\
\hline \multicolumn{3}{|c|}{$\begin{array}{l}\text { BKW test: } 9,01 \\
\text { Adjusted } \mathrm{R}^{2}=0.4685\end{array}$} & \multicolumn{3}{|c|}{$\begin{array}{l}\text { BKW test: } 8,31 \\
\text { Adjusted } \mathrm{R}^{2}=0.5757\end{array}$} & \multicolumn{3}{|c|}{$\begin{array}{l}\text { BKW test: } 7,34 \\
\text { Adjusted } \mathrm{R}^{2}=0.4247\end{array}$} \\
\hline Variable & Coefficient & t- Stat & Variable & Coefficient & t- Stat & Variable & Coefficient & t- Stat \\
\hline $\begin{array}{l}\text { Constant } \\
\Delta \text { CAP } \\
\Delta \text { RISK } \\
\text { ROE }\{1\} \\
\text { REG } 2\end{array}$ & $\begin{array}{l}2.2834 * * \\
3.9555 * * * \\
-0.3959 * * * \\
-0.2767 * * * \\
-0.0115\end{array}$ & $\begin{array}{r}2.52 \\
7.28 \\
-4.51 \\
-3.21 \\
-0.66\end{array}$ & $\begin{array}{l}\text { Constant } \\
\Delta \text { ROE } \\
\Delta \text { RISK } \\
\text { CAP }\{1\} \\
\text { REG } 2\end{array}$ & $\begin{array}{l}0.0986 \\
0.1133 * * * \\
0.1238 * * * \\
-0.0344 \\
0.0007\end{array}$ & $\begin{array}{r}0.42 \\
8.43 \\
11.68 \\
-1.05 \\
0.003\end{array}$ & $\begin{array}{l}\text { Constant } \\
\Delta \text { CAP } \\
\Delta \text { ROE } \\
\text { RISK }\{1\} \\
\text { REG1 }\end{array}$ & $\begin{array}{l}0.5440 \\
6.0174 * * * \\
-0.5307 * * * \\
0.0156 \\
-0.1094\end{array}$ & $\begin{array}{r}0.48 \\
11.84 \\
-4.76 \\
1.02 \\
-0.41\end{array}$ \\
\hline
\end{tabular}

$*, * *$ and $* * *$ indicate statistical significance at $10 \%, 5 \%$ and $1 \%$.

Examination of each equation shows that banks' performances improve due to the regulatory balance sheet constraints. A simultaneous increase in their capitalization together with a decline in the level of risk-taking leads to improvement in performance. For French banks, the Basel Committee requirements related to the Cooke ratio have a positive influence on return on equity. 


\section{Table 4: Results of the simultaneous estimation using internal and external governance variables}

ROE: change in performance (net income/book equity), $\triangle \mathrm{CAP}$ : change in capitalization (equity/total assets), $\triangle$ RISK: change in risk level (risk: risk-weighted assets/total assets), $\operatorname{ROE}\{1\}$ : previous year's $\operatorname{ROE}, \operatorname{CAP}\{1\}$ : previous year's equity, RISK $\{1\}$ : previous year's risk level, REG1: bank's capital adequacy ratio - 8\%, REG2: speed at which the bank adjusts its capital adequacy ratio to regulatory requirements (REG1* CAPt-1), TAILLE: number of directors on the board, INDEP: \% of independent directors on the board, PDG: \% of managers of other firms who are members of the BD, AGE: age of manager, MANPDG: number of CEO positions held by the bank's manager.

\begin{tabular}{|l|l|l|l|l|l|r|}
\hline Performance equation \\
Variable explained $=\Delta$ ROE \\
Usable observations: 71
\end{tabular}

$*, * *$ and $* * *$ indicate statistical significance at $10 \%, 5 \%$ and $1 \%$.

The improvement in performance also leads banks to invest more in the financial markets. These market activities, which are risky by nature, necessitate higher capitalization (required by the regulations but also by shareholders, who demand higher returns for higher investments, even if this involves a certain degree of risk-taking). Our results show that higher performance leads to a higher level of capitalization, which is also influenced by greater risk-taking. This finding confirms the double pressure exercised by regulations and shareholders. From the regulatory standpoint, an increase in risk-taking requires a rise in the regulatory capital. From the shareholders' standpoint, when combined with an improvement in performance, an increase in risk-taking by the bank, particularly in market activities leads to higher capitalization. This simultaneous positive influence between capitalization and risktaking by banks confirms the work of Shrieves and Dahl (1992), Ediz et al. (1998), Aggarwal and Jacques (2001), Rime (2001) and Godlewski (2005).

The results of the risk level equation show that after an increase in capitalization, French banks make investments in riskier activities (market or off balance sheet operations). 
This result argues in favour of shareholder discipline: to meet the demands for returns emanating from the providers of capital, i.e. shareholders, a bank obliged to have a higher capital adequacy ratio will increase risk-taking. Furthermore, in this last equation, we confirm the mutual negative influence between risk-taking and performance in banks. An increase in risk-taking leads to a decline in performance, and conversely, a decline in performance leads to an increase in risk-taking. In the second case, the explanation may lie in the fact that a decline in performance may lead to riskier behaviour by banks in order to satisfy shareholder demands. This greater risk-taking, however, is associated with a parallel rise in capitalization in order to meet the regulatory requirements.

\subsubsection{Explanation of the three variables explained by internal and external governance mechanisms}

Simultaneous estimation of the model shows very clearly that the internal governance variables are relevant to explain the change in performance, the change in capitalization and risk-taking for French banks. External governance variables show that neither the safety cushion held by French banks (REG1), nor the speed at which they adjust their capital adequacy ratio $^{11}$ (REG2) explain the three endogenous variables.

Internal governance by the $\mathrm{BD}$ is essentially reflected in control by independent directors. Control by independents has a positive influence on French banks' performance, because it encourages management in the interests of shareholders. This improvement in performance is accompanied by greater risk-taking (the positive influence of INDEP on $\triangle$ RISK) and a reduction in capitalization (negative influence of INDEP on $\triangle \mathrm{CAP}$ ). The riskreturn tradeoff is managed with the objective of meeting shareholder expectations, through control by independent directors. Similarly, control by peers (directors who manage other firms) within the BD has a positive influence on French banks' performance (confirming Fama and Jensen, 1983) and reinforces the control exercised by independent directors.

Contrary to the findings of Adams and Mehran (2005), the size of French banks' boards of directors negatively influences performance. Since the BDs in our sample have more than 16 members on average, this result shows that these BDs may suffer from a certain lack of effectiveness which then affects performance, as Jensen (1993) explains.

These results show the relevance of the control exercised by the board of directors as 11 This result is explained by the fact that the banks in our sample have a capital adequacy ratio of more
than $8 \%$. 
an internal governance body (contradicting the work of Prowse, 1995). However, this control may be limited due to managerial latitude, which our results show to be a factor in improving banks' performance. The manager's age and number of CEO positions held have a positive influence on performance. The older a manager is, and consequently the more specific and unique experience he has acquired, the more effectively he is able to manage the bank, bringing about improvements in performance.

The positive influence on performance of the number of CEO positions held by the manager shows that the more firms the manager is in charge of, the more his latitude for action allows him to take decisions that improve performance. In the light of our results regarding the impact of this variable on capitalization and risk-taking, we see that this type of manager ultimately behaves like the shareholders. By "diversifying their portfolio of managed firms", he takes decisions that improve performance while also increasing the bank's risktaking and reducing its capitalization. The latitude for action leads the manager to act in the interests of shareholders. These results are in line with the work of Gorton and Rosen (1995), but qualify the findings of Saunders et al. (1990), Demsetz et al (1997) and Jeitchko and Jeung (2005), who base their work on the hypothesis that managers are more markedly riskaverse than shareholders and have a lower propensity to risk-taking.

Table 5: Summary of the assumptions in the model and results of estimations

\begin{tabular}{|c|c|c|c|}
\hline Endogenous variable & Exogenous variable & Expected sign & Result of estimation \\
\hline \multirow[t]{5}{*}{$\Delta$ of capital } & $\Delta$ of risk & - & + \\
\hline & $\Delta$ of performance & + & + \\
\hline & Regulatory discipline & + & Non-significant \\
\hline & Internal BD discpline & - & - (INDEP) \\
\hline & Managerial latitude & + & - (MANPDG) \\
\hline \multirow[t]{5}{*}{$\Delta$ of risk } & $\Delta$ of capital & - & + \\
\hline & $\Delta$ of performance & - & - \\
\hline & Regulatory discipline & - & Non-significant \\
\hline & Internal BD discpline & + & + (INDEP) \\
\hline & Managerial latitude & - & $+(M A N P D G)$ \\
\hline \multirow{5}{*}{$\begin{array}{l}\Delta \text { of performance } \\
\text { (Regulatory approach) }\end{array}$} & $\Delta$ of risk & - & - \\
\hline & $\Delta$ of capital & + & + \\
\hline & Regulatory discipline & + & Non-significant \\
\hline & Internal BD discipline & - & - (TAILLE) \\
\hline & Managerial latitude & + & + (AGE, MANPDG) \\
\hline \multirow{5}{*}{$\begin{array}{l}\Delta \text { of performance } \\
\text { (Shareholder approach) }\end{array}$} & $\Delta$ of risk & + & - \\
\hline & $\Delta$ of capital & - & + \\
\hline & Regulatory discipline & - & Non-significant \\
\hline & Internal BD discpline & + & + (INDEP, PDG) \\
\hline & Managerial latitude & - & + \\
\hline
\end{tabular}




\section{CONCLUSION}

The aim of this study is to propose an explanation for change in performance, capitalization and risk-taking in French banks based on internal and external governance mechanisms. We show simultaneous influences between the three endogenous variables in our model, thus confirming the literature deriving from the empirical study by Shrieves and Dahl (1992). We show that the regulatory discipline is exercised effectively on French banks: improvement of capitalization and a decline in risk-taking help to improve the performance of these banks. Similarly, a reciprocal increase in performance and risk-taking explains the rise in capitalization, and the increase in performance and decline in capitalization explain the decline in risk-taking by these banks. These results indicate that the regulatory discipline imposed by the Basel Committee has an effective influence on French banks.

This regulatory discipline also acts in complement to the discipline exercised by shareholders. Supervision by the board of directors through the presence of independent directors and director-managers who are also managers of other firms disciplines the manager, resulting in an improvement of performance by effective management of the riskreturn tradeoff. Also, experience and the number of CEO positions held by the manager, which reflect his managerial latitude, show that the manager manages his bank in the interests of shareholders, investing in risky activities (as reflected in the trend in recent years' banking activities towards market and off-balance sheet operations), while respecting the external governance constraints imposed by the Basel Committee.

In the light of recent events in the French banking sector and the practices of Basel II or the French Banking Regulation Committee (CRBF) regulation 97-02 on internal control, the current banking crisis that has brought bankruptcy to many pillars of international finance, for example Lehman Brothers, raises doubts over the effectiveness of this complementary discipline by shareholders and the regulatory authorities. Reinforcement of regulatory pressure through Basel II has not in fact avoided the damaging effects of excessive risktaking, as in practice it prevents market discipline or regulatory discipline from operating effectively. Future research should focus on providing some explanation for these phenomena of excessive risk-taking.

\section{REFERENCES:}

- Adams R., Mehran H., 2003, "Is Corporate Governance Different for Bank Holding Companies?", Economic Policy Review, April, pp 123 - 142. 
- $\quad$ Adams R., Mehran H., 2005, “Corporate Performance, Board Structure and its Determinants in the Banking Industry", Working Paper, pp 1-42.

- Aggarwal R., Jacques K.T., 2001, “The Impact of FDICIA and Prompt Corrective Action on Bank Capital and Risk: Estimates Using a Simultaneous Equations Model”, Journal of Banking and Finance, Vol 25, pp 1139-1160.

- Angbazo L., Narayanan R., 1997, “Top Management Compensation and the Structure of the Board of Directors in Commercial Banks”, European Finance Review, pp 239- 259.

- Basel Committee on Banking supervision, 1988, “International Convergence of Capital Measurement and Capital Standards", July, Basel.

- Basel Committee on Banking supervision, 2004, "Convergence internationale de la mesure et des normes de fonds propres", Dispositif révisé, juin, Basel.

- Basel Committee on Banking supervision, 2006, "Renforcement de la gouvernance d'entreprise dans les établissements bancaires", février, Basel.

- $\quad$ Belsley D., Kuh E., Welsch R., 1980, Regression Diagnostics: Identifying Influential Data and Sources of Collinearity, John Wiley and Sons, New York.

- Berger A.N., Bonaccorsi di Patti E., 2003, “Capital Structure and Firm Performance: A New Approach to Testing Agency Theory and an Application to the Banking Industry", Symposium on Corporate Governance in the banking and Financial Services Industries, January.

- $\quad$ Booth J.R., Cornett M.M., Tehranaian H., 2002, “Boards of Directors, Ownership, and Regulation”, Journal of Banking and Finance, vol 26, pp1973-1996.

- Bouaiss K., 2008, "Réglementation du Comité de Bâle, prise de risque et performance des banques européennes", Banque et Marchés, n95, juillet-août.

- Bouwman C.H.S., 2004, “The Governance of Banks: How do Bank Capital and Monitoring Impact PostAcquisition Risk Taking and Performance?", Working Paper, September.

- Ciancanelli P., Gonzalez J.A.R., 2000, "Corporate Governance in Banking: A Conceptual Framework", European Financial Management Association Conference, Athens, June.

- $\quad$ Demsetz R.S., Saindenberg M.R., Strahan P.E., 1997, “Agency Problems and Taking at Banks”, Federal Reserve Bank of New York, Staff Reports 29.

- Ediz, S., Michael I., et Perraudin W., 1998, "Bank Capital Dynamics and Regulatory Policy”, Working paper, Bank of England.

- $\quad$ Fama E., Jensen M.C., 1983, « Separation of Ownership and Control », Journal of Law and Economics, 
vol.26, pp 301-325.

- Godlewski C.J., 2005, "Capital Regulation and Credit Risk Taking in Emerging Market Economics”, Journal of Banking Regulation, vol 6, pp. 128-145.

- Gonzales F., 2005, "Bank Regulation and Risk-Taking Incentives: An International Comparaison of Bank Risk”, Journal of Banking and Finance, vol 29, pp.1153-1184.

- Gorton G., Rosen R., 1995, “orporate Control, Portfolio Choice, and the Decline of Banking” Journal of Finance, vol 50, pp $1377-1420$.

- Hausman J., 1978, “Specification Tests in Econometrics”, Econometrica, vol 46, pp. 1251-1271.

- Heid F., Porath D., Stolz S., 2004, "Does Capital Regulation Matter for Bank Behaviour ? Evidence for German Savings Banks", Deutsche Bundesbank, Working Paper

- Jacques, K. T., Nigro P., 1997, "Risk-Based Capital, Portfolio Risk and Bank Capital: A Simultaneous Equations Approach,” Journal of Economics and Business, 49, pp. 533-547

- Jeitschko T.D., Jeung S.D., 2005, “Incentives for Risk-Taking in Banking - A Unified Approch”, Journal of Banking and Finance, vol 29, pp 759- 777.

- Jensen M.C., 1993, “The Modern Industrial Revolution, Exit and the Failure of Internal Control Systems”, Journal of Finance, pp 831-880.

- Kahane Y., 1977, “Capital Adequacy and the Regulation of Financial Intermediaries”, Journal of Banking and Finance, vol.1, pp 207-218.

- Keeley M.C., 1990, “Deposit Insurance, Risk, and Market Power in Banking”, American Economic Review, vol 80, n5, pp. 1183-1200.

- Koehn M., Santomero A.M., 1980, "Regulation of Bank Capital and Portfolio Risk”, Journal of Finance, vol.35, pp 1235-1244.

- Llewellyn, D.T., 2001, “A Regulatory Regime for Financial Stability”, Oesterreichische Nationalbank (Austrian National Bank), Working Paper $n^{\circ} 48$.

- $\quad$ Macey J.R., O’Hara M., 2003, “The Corporate Governance of Banks”, Economic Policy Review, April, pp 91 - 107.

- Merton R.C., 1977, “An Analytic Derivation of the Cost of Deposit Insurance and Loan Guarantees”, Journal of Banking and Finance, Vol1, pp 3-11.

- Murinde V., Yaseen H., 2004, "The Impact of Basel Accord Regulations on Bank Capital and Risk Behaviour: 3D Evidence from the Middle East and North Africa (MENA) Region", Third International 
Conference of the Centre for Regulation and Competition, Working Paper.

- Prowse S.D., 1995, “Alternative Methods of Corporate Control in Commercial Banks”, Economic Review Federal Reserve Bank of Dallas, vol 24, pp 24-36.

- $\quad$ Rime B., 2001, “Capital Requirements and Bank Behaviour: Empirical Evidence for Switzerland », Journal of banking and finance, $\mathrm{n}^{\circ} 4$, pp 789-805.

- $\quad$ Rochet, J-C., 1992, “Capital Requirements and the Behaviour of Commercial Banks”, European Economic Review, 36, pp. 1137-1178

- Saunders A., Strock E., Travlos N.G., 1990, “Ownership Structure, Deregulation and Bank Risk Taking”, Journal of Political Economy, vol.78, pp 1-26.

- $\quad$ Shleifer A., Vishny R.W., 1989, "Management Entrenchment: the Case of Manager-Specific Investments", Journal of Financial Economics, pp123-139

- $\quad$ Shrieves, R. E., Dahl D., 1992, “The Relationship Between Risk and Capital in Commercial Banks”, Journal of Banking and Finance, 16, pp. 439-457.

- $\quad$ Spencer D., Berk K., 1981, “A Limited Information Specification Test”, Econometrica, vol 49, pp. 10791085.

- Van Roy P., 2003, “The Impact of the 1988 Basel Accord on Banks' Capital Ratios and Credit Risk-Taking: An International Study", Working Paper. 